\title{
Pak-Iran Relations: Challenges and Expectations (2001-2012)
}

\author{
* Syed Sajjad Haider, PhD Scholar \\ ** Dr. Gulzar Ahmad, PhD (Corresponding Author) \\ *** Dr. Muhammad Khurshid, Professor
}

\begin{abstract}
This paper endeavors to analyze the relations between Pakistan and Iran, during the past more than seven decades, especially after 9/11. The relations between both countries remained normal and friendly, but with a slight divergence. These relations became very critical after 9/11 due to the huge pressure of the US. There are many areas of divergence between these two countries such as the gas pipeline treaty, diplomatic support of Pakistan in the Iranian nuclear program, trade, and economic issues. In this paper, an attempt has been made to critically highlight and discuss the challenges and expectations emerging after the Islamic revolution and during 2001 to 2012. The core objectives of the study are to know about the nature of Pak-Iran relations in the past, to describe the nature of PakIran relations from 2001-2012, to measure the influence of world powers on Pak-Iran relations to analyze the challenges facing both the countries, etc. Suggestions are also made to improve the relations between both Islamic republics' countries in the region. Pakistan's and Iran's concerns and interests are related to the new regional and international atmosphere. New problems and new opportunities have been created for both countries, affecting their bilateral and multilateral relations since the events of September 9, 2001. The two countries should devote more energy to increase their economic trade, strengthen security cooperation, and identify practical ways to cope with the problems of the region.
\end{abstract}

Keywords: Challenges, Competition, Cooperation, Pak-Iran Relations, Islamic Revolution, Ties Introduction

Pakistan and Iran are close neighbors, sharing a $909 \mathrm{Km}$ border on the western side. Both countries share strong historical, religious, cultural, and linguistic bonds. Iran was the first country to accord international recognition to Pakistan when it was established in 1947. Both the countries have supported each other financially, economically, militarily, and politically. Pakistan and Iran have been stuck in a friendly relationship since Pakistan's independence in 1947 and Pakistan is looking forward to consolidating this bond of bilateral relations. Although the relations between the two states were never very hostile, however, they saw several fluctuations due to many factors. These factors include the rise of militancy within Pakistan, the sectarian rivalry between Iran and Saudi Arabia that has also sowed the seeds of Shia-Sunni partition within Pakistan (Farooq, 2010), the Taliban's support for Pakistan in Afghanistan, the US-Pakistan alliance in the fight against terrorism and Iran's efforts to establish and maintain good relations with India. Nevertheless, so far both Pakistan and Iran have maintained cordial relations between the two for the sake of mutual political and strategic interests and have resolved matters between them.

As the Iranian embassy in Islamabad has been summarized, Pakistan-Iran cooperation is based on the following key sectors: Geography, culture, and traditions, similar economic and political perspectives, comparative strategic thinking, and defense cooperation (especially during the cold war and after the Islamic revolution), nuclear non-proliferation, expansion of political, diplomatic and moral support for Kashmir independence struggle, consolidation of interests on issues of establishing New International Economic Order in regional and global politics (Iran, 2021). Religion forms also a strong foundation of Pakistan-Iran relations. As expressed in the words of Pakistan's former prime minister, Benazir Bhutto, "Islam binds us together in a spiritual bond which others cannot share in the

\footnotetext{
* Department of Pakistan Studies, Islamia University of Bahawalpur, Pakistan

Email: sajjadhaider779@gmail.com

** Punjab Education Department, Pakistan Email: gulzar422@gmail.com

*** Department of Pakistan Studies, Islamia University of Bahawalpur, Pakistan
} 
same manner. Islamic principles have helped to guide our people and shape our destiny (Pathan, 2021)

However, it will be easy to understand that due to the above common factors the two states have maintained over the past six decades. The fact is that Pakistan-Iran relations are extremely complex. . The concept that their existence is constantly threatened or challenged provides their Allies but the same idea has also made them extremely nervous and has shadowed their relations again and again. For example, in recent days, Islamabad has been concerned about strengthening Iran's relations with India while Tehran has expressed concern about Pakistan-Saudi relations as well as US-Pakistan relations.

\section{Significance of the Study}

In this paper, an attempt has been made to critically highlight and discuss the challenges and expectations emerging after the Islamic revolution and during 2001 to 2012. The core objectives of the study are to know about the nature of Pak-Iran relations in the past, to describe the nature of PakIran relations from 2001-2012, to measure the influence of world powers on Pak-Iran relations to analyze the challenges facing both the countries, etc

\section{Research Methodology}

It is a descriptive study. The qualitative method approach is used to collect the data. Government records, official statements, newspaper articles, official websites, reports, books, research articles, magazines etc are used to collect analytics data.

\section{Summarizing Pakistan-Iran relations}

By and large, Pakistan and Iran have maintained cordial relations with each other since the former country's independence in 1947. Iran was the first country to recognize Pakistan as an independent state and the shah of Iran was the first head of state to pay an official visit in March 1950 (Razvi, 1971, p. 203). A treaty of friendship was also signed in the same month when Iran became the first country to recognize the establishment of Pakistan as an independent state. The treaty envisaged the improvement of economic and cultural bonds between the two countries and therefore strengthened their geopolitical relations.

In its first war with India in 1948, Pakistan gained much ease with its friendship with Iran when its survival was in danger (Iran, 2021). Despite a shared Islamic identity and communal division, the relationship between the two neighbors became the basis, especially in the years after the Islamic revolution in Iran in 1979. Besides, through most of the cold war era 'exchange of strategic goals achieved by the Anglo-American alliance' fostered a positive Pakistan-Iran relationship, strengthened during joint opposition towards Soviet invasion of Afghanistan (Alam, 2004, p. 527). Common security concerns also led to various security complexes in which the two countries joined as members such as the South East Asia Treaty Organization (CETO) and the Central Treaty Organization (CENTO).

However, as a result of the frustration of two neighboring countries with western military alliances in the backdrop of a growing wave of disunity, the two sought to build close economic ties in the form of Regional Cooperation for Development (RCD) established in 1964 to promote close economic and cultural cooperation between Pakistan, Iran and Turkey. Despite the extreme pressure of the Gulf States, especially Saudi Arabia, during the Iran-Iraq war, Pakistan maintained an unbiased position (Kfir, 2011). Once the US-led gulf surfaced in the post-Cold War era, a new dimension to the Pakistan-Iran security relationship emerged, that of nuclear cooperation (Alam, 2004, p. 527). Through Dr Abdul Qadeer Khan, a Pakistani scientist who established and headed Pakistan's nuclear program, Pakistan played a critical role in the development of Iran's nuclear program. Nuclear experts believe that Iran would not have been able to acquire the ability of uranium enrichment with the help of Dr Abdul Qadeer Khan's global nuclear network (Zarif, 2009).

Although the official position of Pakistan's government has been that the transfer of devices took place without any government or military involvement and that individuals acted on their own accord coming together for their financial gain, it is unlikely that the devices and components associated with nuclear technology could be moved without any knowledge and support from government officials (Zarif, 2009). However, relations between Pakistan and Iran officially to the state seem to have disappeared by the early 1990s and since then nuclear relations mainly operate through Dr Abdul Qadeer Khan network (Zarif, 2009). When the Soviet Union intervened in Afghanistan in 1979, Pakistan played a front-line state role in leading a guerrilla war with the US, 
ending Iran's active intervention in the Afghan conflict. Soviet withdrawal after fighting in Afghanistan enabled Iran once again to take an active part in Afghanistan to advance its interests which contradict Pakistan's interests in Afghanistan. This resulted in intense hostility between the two neighboring countries as Pakistan was supporting the Taliban while Iran was inclined towards the Northern Alliance.

Another reason for this hostility was the independence of the Central Asian States, as both wanted the trade routes of hot water to be shifted to their territories. Another important factor was India's role in helping the Northern Alliance and connecting the seaport of Chahbahar with Afghanistan and helping Iran build road infrastructure (Hanif, 2012). Pakistan and Iran also suffered strains in their relationship due to sectarian violence which emerged in Pakistan under the rule of President Zia-ul-Haq and has continued to thrive in the country since then. Moreover, over a decade, both Pakistan and Iran faced numerous geopolitical and domestic challenges which may affect the inter-state relationship in yet unknown ways. For example, since the turn of the century, Iran has been in the line of fire for its aspirations to acquire nuclear technology and was termed as being part of the axis of evil.

The country has been increasingly marginalized by the US since the Islamic Revolution in 1979. Meanwhile, it has been facing internal conflict between the liberals and conservatives. On the other hand, Pakistan has been criticized for transferring nuclear technology to Iran. It is embroiled in ever-increasing problems of extremism and intolerance, ethnic and sectarian violence. It is fighting internal wars on several fronts and is held hostage by the resident US forces that are threatening its sovereignty. Therefore, in this scenario of external and internal uncertainty, Pakistan-Iran relations could undergo a drastic change.

\section{Need for an alliance}

The need for common security ideas and unity for both Pakistan and Iran, the concept of security is rooted in their social, political, military, and regional weaknesses. In the case of Iran, the preservation of Islamic ideology and belief has significant importance, and sees state security as the ability of the state to preserve territorial integrity and ensure political sovereignty (Alam, 2004, pp. 527-528). "The security perceptions of the two countries are highly influenced by geography and politics. In the case of Iran, western Asia (especially the Persian Gulf) represents the country's key security interests, while its northern and eastern parts have secondary importance. Meanwhile, India holds first and foremost importance for Pakistan, Afghanistan is almost second. As a result, changes in either the Persian Gulf or one of South Asia will affect both states.

In a similar situation, security complexes that cover geographical regions will continue to play a vital role in regional formation and alliances. Pakistan and Iran signed various US-led security pacts in the 1950s while India adopted an independent policy of non-alignment. Iran and Saudi Arabia have been traditional adversaries. After the Islamic revolution in Iran these difficulties intensified due to religious unity in Iran (which was opposed to Saudi Arabia), the two states have not faced each other in direct war, but have been involved in proxy wars since 1979 and one of the battlefields for both has been Pakistan. Saudi Arabia is not fond of Pakistan's friendly relations with Iran. On the other hand, Saudi Arabia views Iran's nuclear program as a direct threat to its security and interests in the region. The recent troubles in Bahrain against the regime supported by Saudi Arabia triggered under the patronage of Iran, further worsened Iran-Saudi relations.

\section{Islamic Revolution of 1979 and changing foreign policy of Iran}

The Islamic revolution in 1979 drastically changed the relations between the US and Iran. The Islamic revolution empowered leaders who shared anti-US sentiments and firmly believed that the US had tried to maintain the ex Shah of Iran in power despite mass demonstrations demanding his dismissal. The more radical revolutionaries harbored deep suspicion that the US was plotting to restore the Shah to power and that the provisional government seeks accommodation with the US. To end all ties with the US, these revolutionaries took advantage of the prolonged hostage crisis (Metz, 1987) as well as they attacked the US embassy in Tehran. This effectively ended US-Iran relations and started a great rivalry between the two countries.

After the Islamic revolution in Iran, the country's foreign policy was deeply rooted in two main concepts, neither the East nor the West and export of the Islamic revolution (Metz, 1987). According to the previous concept, a major aspect of Iranian foreign policy was to avoid it either in Western capitalism or Eastern socialism, all forms of political, economic, and cultural dependence 
and depend on Islam (Metz, 1987). Instantaneously, under the pretext of exporting a revolution, Iran announced the establishment of an Islamic world order to gain alliance with Islamic countries founded on solidarity rather than the current world order based on the Westphalia system of nation-states (Winter-Spring 2008-09, pp. 101-114). After the Islamic revolution, the Islamic Republic continued to occupy all three islands at the mouth of the Strait of Hormuz, Raza Shah monitored for security reasons since 1971. It was also claimed by the UAE, thus increasing strategic tension. The case speeds up relations between the UAE and Iran. Saudi Arabia has supported the UAE and was supported by the Gulf Cooperation Council (GCC), which was created to combat Iran's partial defenses. Pakistan has distanced itself from the conflict, advocating peaceful settlement.

\section{Rise of the Taliban and Sunni militancy in Pakistan}

Both Pakistan and Iran maintained close ties during the Soviet invasion of Afghanistan and Iran, which supported several mujahedeen groups to counter the Soviet armed forces. Furthermore, they sheltered millions of Afghan refugees in their territories during and after the conflict (Kfir, 2011). However, with the Soviet retreat from Afghanistan, relations between Pakistan and Iran have suffered deeply, as the Taliban with their radical Sunni ideology sponsored by the Pakistan ISI massacred thousands from the Afghan Hazara community. In this situation, Iranian Revolutionary guards were encouraged to join Afghanistan to protect the Hazara community and prevent the wave of radical Sunni Islam (Kfir, 2011).

By the early 199s, Sunni-Shia violence in Pakistan was on the rise. The country had started cutting the Islamization crop in Zia-ul-Haq's Pakistan. With the regime change in Pakistan and an increase in power with Zia ul Haq's government in 1977, Pakistan started its way on a Sunni militancy path leading to increased sectarian violence including targeted killings of Iranian diplomats In Pakistan. This resulted in a permanent deterioration in Pakistan-Iran relations, which in the late 1990s when Pakistan-backed Taliban captured most of Afghanistan. However, once after the September 11, 2001, terrorist attacks and crackdown against extremists in Pakistan, Pakistan withdrew Taliban support, most of the conflict between the two neighbors disappeared.

The 'axis of evil' was seen as a surprising return to Tehran's cooperation with Afghanistan in Bonn (D'Souza, 2011, p. 2). In the light of growing US rivalry with Iran, the latter will welcome any opportunities to develop an integrated Afghan strategy with Pakistan, if it should be interested in a strategic partnership with sincerity. While Iran welcomes the end of the Taliban regime and has provided support to the central government in Afghanistan, if the us withdraws from Afghanistan and removes its military bases from the Iranian border in the country, Iran's security interests will be better served by close ties with Pakistan, against the backdrop of cooler ties between the United States and Pakistan, will facilitate Iran significantly in achieving this goal (Bayyenat, 2011). On the other hand, Washington's accusation of "destabilization of Afghanistan has also deteriorated relations between the United States and Pakistan over Afghanistan by ISI, while Pakistan's stance is that the US is not doing enough to stop Afghani terrorism affecting Pakistan (Kfir, 2011).

In the future, we can expect Iran and Pakistan to work together to solve the problem of Afghanistan. According to Mir Javednafar, Iran is in the main interest of pulling Pakistan away from the US given the growing differences between Islamabad and Washington over Afghanistan and the drone attacks. Iran can take advantage of its energy influence and political popularity to gain Pakistan's support (Javedanfar, 2012).

\section{India, Iran, and Pakistan}

In recent years, Pakistan has watched very carefully the emerging India and Iran relations, especially since its belligerent neighbor, India has begun spreading its wings far and wide after September 2001, and Pakistan's perception of threat from India has increased. New Delhi's self-perception of power with the US as a result of the $9 / 11$ terrorist attacks at the regional level. Long term view of its global rise, inspired by the mythical religion of Brahmin supremacy, now saw an unprecedented opportunity to gradually feel the dream (Jafar, 2005, p. 17). So, within three months after September 2001, India's parliament under the pretext of an attack that provided no evidence, India began to animate its entire military machinery for pre-emptive attacks against Pakistan. The latter took defensive measures, and India had to stop its advances (Jafar, 2005, p. 17). Many people in Pakistan and the region believe it was Islamabad's nuclear deterrence that stopped the Indian invasion, the idea reinforced as a result of the Bombay terrorist attacks of November 2008. 
Iran, meanwhile, was building a healthy relationship with India. President Khatami went on an official visit in January 2003 and signed various agreements, one of the most important 'strategic partnerships' or the famous declaration of New Delhi. 'Iran and India also agreed in the development of transport links between the two countries, which can' fundamentally alter the region's geopolitics (Mohan, 2003). The plan was argued, 'Iran and India leverage gains will increase the Great Game of access to Eurasian landlocked resources and markets, while rendering Pakistan irrelevant to a developed strategic framework (J.Aaron, 2003). Recognition as a key regional player by the international community, for example, in 2005, India voted in favor of the International Atomic Energy Agency resolution which concluded that Iran's failures and breaches constitute noncompliance with the Nuclear Non-Proliferation Treaty and called on Iran to return to the negotiating process (Jafar, 2005, p. 20). Moreover, India's nuclear deal with the US also indicates supremacy first and foremost India's self-interest. On the other hand, Pakistan has consistently advocated Iran's inalienable right to nuclear technology for peaceful purposes.

On a gas pipeline project between India, Pakistan, and Iran as India 'is pulling its feet' and some authors believe it may face its looming hatred for the development of peace and stability with Pakistan (Khan, 2012, pp. 121-140). Pakistan, on the other hand, has pursued the gas pipeline project despite US pressure. It is believed that India has created difficulties for Iran and Pakistan regarding the exploitation of local population cross-border ethnic contacts in both countries. The pipeline plan will be extremely beneficial for both Iran and Pakistan. Iran sees the pipeline not only economic lifeline at a time when the US and its European allies are trying to weaken it economically but also a chance, should the pipeline extend to India or China, creating an unexpected long-term political situation and economic dependence of billions of Chinese and Indian consumers on its gas.

Pakistan, for its part, sees the pipeline as a solution to its energy conservation challenge. Pakistan's domestic gas production is decreasing and its import dependence is increasing over leaps and bounds. By linking itself to the world's second-largest gas reserve, Pakistan will guarantee reliable supply for decades to come. If the pipeline was to be extended to India, it could also be a source of stability in the strained relations between India and Pakistan. Under any scenario of pipeline expansion that makes Pakistan a transit state, Islamabad receives a transit fee of hundreds of million dollars per year. Furthermore, Iran and Pakistan are extremely cautious of the close ties that India has developed with Israel since the latter harbors tremendous animosity for both Iran and Pakistan. In April 2009, a senior leader from the Israeli government termed Pakistan as Israel's biggest strategic threat (Mishra, 2009).

In the larger security context, India sees an opportunity to advance its regional hegemonic desires in aligning itself to the US regional approach towards Afghanistan and determining the possibility of deployment of Indian troops in that country. If this were to materialize, then India, acting as a proxy to its western as well as Israeli allies, would effectively extend its strategic reach from Afghanistan in the north to the Persian Gulf in the south, where it already has a naval presence (Jafar, 2005, p. 23). Political analysts had observed that Iran and Pakistan needed to get closer to each other since imperialism, both territorial and extraterritorial, surrounding both countries fail to close their ranks on the eve, either individually overcoming the challenge (Cheema, 2010).

Recently, Iran openly supported Kashmiris and spoke against India on several occasions in 2010. In September 2010, the Iranian foreign ministry condemned the Indian action against protesters in Jammu and Kashmir, demonstrating against the desecration of the Holy Quran in the West. An Iranian TV channel showed a clipping of this act, which was later banned by India in Jammu and Kashmir. This brought a strong response from Iranians, and an Iranian spokesperson, Ramin Mehmanprastst, said 'it is perfectly appropriate for Muslims to react to the desecration of the Holy Quran' and demanded the Indian government to show 'self-restraint (Samanta, 2010). Furthermore, during his Hajj message in 2010, Iran's Supreme Leader Ayatollah Ali Khamenei made a stern statement supporting Kashmir. He appealed to the Muslims all over the world as follows:

Today the main duties of the elite of the Islamic Ummah of Islam is to provide help

to the Palestinian nation and besieged people of Gaza, to provide sympathy and support to the nations of Afghanistan, Pakistan, Iraq, and Kashmir, to engage in struggle and resistance against the aggression of the United States and the Zionist regime, to safeguard the solidarity of Muslims and stop tainted hands and mercenary voices that try to damage this unity, to spread awakening and the sense 
of responsibility and commitment among Muslim youth throughout Islamic communities.

Pakistan and Iran moved closer in 2011 when senior Pakistani officials, in open defiance of the US made several visits to Iran to discuss the proposed gas pipeline project which offers considerable benefits for them both.

The US has openly opposed the project and is becoming more aggressive about this matter. The US has said that the gas pipeline project will violate US sanctions on substantial financial deals with Iran and as a result, another law was passed limiting any transaction with central Iranian Banks (Dawn, 2012). However, 'the Economic Coordination Committee took a major step in this direction by approving the $\$ 200$ million sovereign guarantee for the Iran gas project and also agreed in principle on the appointment of the consulting consortium headed by China's industrial and commercial bank 'experts, however, predict that the Chinese bank, on its own, has been under US pressure (Dawn, 2012).

While gas pipeline momentum is increasing in Pakistan and Iran, as both countries try to resist US hegemony, it remains to be seen what will transpire Meanwhile, Iran is looking to consolidate its position and secure itself against US pressure. Iran has laid a pipeline near the border as per agreement, that it should be connected to the terminal at its own expense, Will Islamabad find it difficult to arrange counterpart fund. However, Russia may be interested in this project.

\section{Expansion of external relations}

Iran is expanding its ties with other regional players, such as Turkey, and is finalizing similar arrangements to launch economic cooperation jump. Trade between Iran and Turkey was expected to touch 15 billion dollars in 2011, while between Pakistan and Iran is only about 150 million dollars worth of export to Iran and 1.2 billion dollars in imports from Iran to Pakistan. Iran has also been looking more towards Latin America (Cynthia J. Arnson). Iran has also sought to improve its regional position besides economic agreements and increased trade with its neighbors. Iran's stature in the region has risen, mainly due to the Arab Spring throughout 2010. The collapse of pro-US regimes, in the popular Arab awakening, vindicated Iran's anti-American stance (Hussain, 2011, pp. 43-58).

As noted by a Pakistani academic, Iran is one of the countries that has benefited the most from the fall of the pro-US regimes, popular Arab resistance, and the resumption of Iran-Egypt ties, 'Israeli isolation and Palestinian coalition government (Times, 2011). Iran has also openly supported Arab awakening, including in Bahrain, despite efforts to restore Saudi Arabia's position in the region (Hussain, 2011, pp. 43-58). At this time, Pakistan has also drawn its attention to regional countries like Iran, Afghanistan, China, India, Russia, and the central Asian republic to distance itself from the US. Pakistan believes that by improving its relations with its neighbors, it will reduce dependence on the US. This pattern shift is an explanation of Pakistani officials coming to Iran in 2011 and not giving India the status of the most favored nation.

\section{Pak-Iran relations: will cooperation continue?}

When analyzing the relationship between Pakistan and Iran, it is important to reflect, even in the case of differences between the two neighbors, the formal contacts were never completely broken. The lowest point in Pakistan-Iran relations occurred between 1992 and 2002 due to sectarian violence and the support of Pakistan's Taliban. During this difficult period, no Iranian President visited Pakistan. Nevertheless, at a subdued level, though, cooperation between the two countries continued. At the same time when the Taliban withdrew from Afghanistan (Iqbal, 2001). Pakistan and Iran have drawn closer still due to their worsening relations with the US during 2011. In the case of Pakistan, the fostering of closer ties with Iran occurred as a result of the Raymond Davis issue, US attack and killing of Osama bin Laden, Salala incident, and killing of 26 Pakistani soldiers. Pakistan became bolder in its interaction with Iran and there was increasing momentum for the Gas Pipeline Project. The President of Pakistan visited Iran twice in less than a month. First, he visited Iran in June 2011 to attend the sixth International Conference on Global War on Terrorism (GWOT) where Afghanistan, Pakistan, and Iran came together to discuss various common issues and devise strategies on a possible solution.

Asif Ali Zardari once again visited Iran in July 2011 to pursue and strengthen bilateral relations with Iran. The Iranian President also stressed that the Pak-Iran gas pipeline plan will be completed by the end of 2012 and will help resolve Pakistan's energy crisis (Gopand, 2011). After the meetings, there were more official visits between the two countries to discuss trade and other strategic 
interests. Meanwhile, with both Pakistan and Afghanistan deepening their relations, Iran has also been demonstrating its might over the Strait of Hormuz and confronting US pressure. Furthermore, in response to the European Union's step-by-step ban on Iranian oil effective from July 2012, Iran has halted oil exports to France and Britain. Although the two European states are not major importers of Iranian oil, the move has mainly been raised as a warning to other EU nations that are major users of Iranian oil such as Italy (importing $13 \%$ or 185,000 barrels per day), Spain (importing $12 \%$ or 161,000 barrels per day), and Greece (importing 30\% or 103,000 barrels per day) (India, 2012).

Relations between the United States and Pakistan were also caused by recent resolutions moved from the group of US Congressmen endorsing the Baloch people's right to self-determination. The statement explained that since the Baloch people are subjected to violence and extrajudicial killings in Pakistan, they have the right to self-determination and their own sovereign country and they should be allowed to choose their status (Rajghatta, 2012). Pakistan strongly protested against this resolution and it appears even more difficult for Pakistan and the US to return to a friendly relationship.

On February 18, 2012, amid growing tensions between Tehran and Israel, heads of Pakistani, Iranian, and Afghan states sat together at a regional summit in Islamabad. The summit took place at a time when American relations with both Iran and Pakistan are at their lowest point and led by someone other than the United States to attack Iran, the world is seeing a rising momentum. As the US tightened the reach around Iran, launched an aggressive campaign against Pakistan, and passed negative resolutions against the two countries, we can expect them to come closer in the coming months. However, a US-backed Israeli strike or even worse, an American attack on Iran will plunge the entire region into chaos, and it will be detrimental to the interests of all, including the US. If war escalates, it can force Americans into a protracted conflict that they cannot afford. At least Russia will refuse to overwhelm Iran or rule forcefully in Iran. According to contemporary strategic perception, the Islamic republic is more important to Moscow than Syria in which it strongly supports the US and NATO.

\section{Conclusion}

Since the fall of the Taliban from Afghanistan in 2001, Iran and Pakistan have tried their best to improve strained relations in the past by policy differences over Afghanistan. Consequently, both Tehran and Islamabad have supported the political process in Afghanistan by the Bonn agreement between the Afghan political factions, while reaching out to the government of President Hamid Karzai in his efforts to rebuild Afghanistan. Regular exchanges between the officials of Pakistan and Iranian intelligence have been ongoing since October 2001. Both the states agreed to solve the problems of security and borders in a special safety committee. Iran is pleased with the statements by Musharraf that Pakistan's nuclear assets are under strict control custody that any clandestine proliferation network was dismantled. In conclusion, Pakistan's and Iran's concerns and interests are related to the new regional and international atmosphere. New problems and new opportunities have been created for both countries, affecting their bilateral and multilateral relations since the events of September 9, 2001. The two countries should devote more energy to increase their economic trade, strengthen security cooperation, and identify practical ways to cope with the problems of the region (Ahmad, Khurshid, \& Asadullah, 2020, pp. 1-21).

\section{References}

Ahmad, G., Khurshid, M., \& Asadullah, A. (2020, January 1). Socio-economic development under the Development Authority. Revista Dilemas Contemporáneos: Educación, Política y Valores, Vol. VII (No. 2), 1-21.

Alam, S. (2004, October). Iran-Pakistan Relations: Political and Strategic Dimensions. Strategic Analysis, Vol.28, Issue 4, October 2004, p.527. , 28(4), 527.

Bayyenat, A. (2011, July 25). The Courtship of Iran and Pakistan: Foreign Policy in Focus. Retrieved from http://www.fpif.org/articles/the_courtship_of_iran_and_pakistan

Cheema, S. A. (2010, December). Indian-Iran Relations: Progress, Challenges and Prospects. India Quarterly, Vol. 66(No.4), 383-396.

Cynthia J. Arnson, H. E. (n.d.). . Iran in Latin America: Threat or 'Axis of Annoyance(No.23). Wilson Center Reporter on the Americas. Retrieved from http://www.wilsonscenter.org/sites.default/ files/Iran_in_LA.pdf 
D’Souza, S. M. (2011, September 1). Iran, US, and the Afghan Conundrum. ISAS Insights(No. 132), $1-11$.

Dawn. (2012, January 4). Pak-Iran Gas Pipeline to Violate Sanctions: US. Karachi, Pakistan: The Dawn.

Farooq, A. (2010, July 18). Iranian Saudi War Spills Over to Pakistan. Pakistan: Viewpoint Online.

Gopand, A. A. (2011, July 21). Pak-Iran relations. Karachi, Sindh, Pakistan: Pakistan Today.

Hanif, M. (2012, October 19). How to boost Pak-Iran ties. Peshawar, KPK, Pakistan: The Frontier Post.

Hussain, N. (2011, July). Unrest and Revolt in the Arab World: Impact on Regional Security. Pakistan Horizon, Vol. 64(No.3), 43-58.

India, T. o. (2012, February 20). Iran takes tough: Halts oil sales to France, Britain. India: Times of India.

Iqbal, N. (2001, December 13). 'New era in Pakistan, iran ties. Asia Times Online.

Iran, E. o. (2021, March 3). Pak-Iran Relations Since Islamic Revolution: Genisis of Cooperation and Competition. Retrieved from Embassy of The Islamic Republic of Iran: http://www.iranembassy.pk/en/political-section/592-pak-iran-relations-since-islamicrevolution-genisis-of-cooperatio-and-competition.html

J.Aaron, S. (2003, August). Straddling Fault lines: India's Foreign Policy towards the Greater Middle East. (No. 7). CSH Occasional.

Jafar, G. (2005, August ). Pakistan-Iran Relations: The Security Scenario. Strategic Studies, Vol. 28(No.4), 17.

Javedanfar, M. (2012, May 28). Iran's new opportunity to improve relations with Pakistan. Retrieved from Al-monitor: http://www.al-monitor.com/pluse/originals/2012/al-monitor/irans-pakistaniopportunity-in -a. html\#ixzz2DV04j2Ld.

Kfir, I. (2011, October 25). Iran-Pakistan Relations and their Effect on Afghanistan and the US. Retrieved from Institute for National Security and Counterterrorism, Syracuse University: http://insct.org/commentary-analysis/2011/10/25/iranian-pakistan-relations-and-their-effecton-Afghanistan-and-the-us

Khan, Z. A. (2012, January-June ). Balochistan Factor in Pak-Iran Relations: Opportunities and Constraints. South Asian Studies, Vol.27(No.01), 121-140.

M. R, D. a. (Winter-Spring 2008-09). Iran's Foreign Policy in Post-Revolution Era: A Holistic Approach. The Iranian Journal of International Affairs, Vol XXI(No.1-2), 101-114.

Metz, H. C. (1987). Iran: A Country Study. Washington: GPO for the Library of Congress.

Mishra, H. (2009, April 22). Pak, Afghans are the biggest threat to Israel. India: Press Trust of India.

Mohan, C. R. (2003, January 26). India, Iran unveils road diplomacy. India: The Hindu.

Pathan, D. D. (2021, March 3). Address by Prime Minister Benazir Bhutto to the Iranian Majlis, Tehran. Retrieved from Gul Hayat Institute: http://www.drpathan.com/index.php/addressand-speeches/shaheed-muhtarma-benzir-bhutto-speech-07-november-1995-tehran

Rajghatta, C. (2012, February 18). Balochistan resolution in US Congress drives Pakistan crazy. The Times of India.

Razvi, M. (1971). The Frontiers of Pakistan: A Study of Frontier Problems in Pakistan's Foreign Policy. Karachi: National Publishing House.

Samanta, P. D. (2010, October 2). Iran slams India over J\& K protests, India hits back issues demarche. India: The Indian Express.

Times, T. (2011, June 2). Iran, Egypt should establish an axis of anti-Zionism: Ahmad inejat. Iran: Tehran Times.

Zarif, M. (2009, July 24). Technology Sources for Iran's Nuclear Program. Retrieved from Iran Tracker: http://www.irantracker.org/nuclear-program/technology-sources -Iran's-nuclearprogram. 